\section{ЛИТЕРАТУРА}

1. Аналоги простагландинів як додатковий фактор покращення перфузії ока при очному ішемічному синдромі / [Завгородня Н. Г., Безденежна О. О., Рудичева О. А., Колісник О. А.]. // Сучасні медичні технології. -2009 . - № 2. - С. 25-31.

2. Павлюченко К. П. Новый метод лечения острых нарушений кровообращения в сетчатке и зрительном нерве у пациентов с различным тонусом вегетативной нервной системы / Павлюченко К. П., Джорджуа В. С., Могилевский С. Ю. // Офтальмологический журнал. - 2008. - № 6. - С. 35-38.

3. Пат. України, МПК (2009) А 61 F 9/00. Спосіб лікування очного ішемічного синдрому / Завгородня Н. Г., Безденежна О. О., Завгородня Т. С., Рудичева О. А.; власник ДЗ «Запорізька медична академія після- дипломної освіти МО3 України». - № 40115; заявл. 24.10.2008; опубл. 25.03.2009, Бюл. № 6.

4. Пути улучшения микроциркуляции при глазном ишемическом синдроме / [Н. Г. Завгородняя, Е. А. Колесник, Т. С. Завгородняя и др.]. // Офтальмологический журнал. - 2008. - № 1. - С. 32-36.

5. Семесько С. Г. Функции эндотелия и свободнорадикальное окисление при хронической ретинальной сосудистой недостаточности: дис. ... д. мед. наук: 14.00.16: Семесько С. Г. - С. - Петербург, 2006. $389 \mathrm{c}$.

6. Тарасова Л. Н. Глазной ишемический синдром / Тарасова Л. Н., Киселева Т. Н., Фокин А. А. - М.: Медицина, 2003. - $173 \mathrm{c}$.

Поступила 22.12.2011

Рецензент д-р мед. наук В. В. Савко

\title{
IMMEDIATE AND LONG-TERM RESULTS OF TREATMENT OF CHRONIC ISCHEMIC OPTIC NEU- ROPATHY USING LOCAL HYPOTENSIVE THERAPY
}

Zavgorodnyaya N. G., Bezdenezhnaya O. A., Bezdenezhniy S. V.

\section{Zaporozhye, Ukraine}

There was carried out the analysis of the efficacy of complex treatment in patients with chronic ischemic optic neuropathy with the use of local hypotensive therapy. There was studied the dynamics of changes in the visual function and eye hemodynamics in 3 months and 1 year from the beginning of therapy. A statistically significant advantage of complex treatment supplemented by the administration of prostaglandin F2a analogues, compared with traditional therapy is revealed.

УдК 617.711-002.3-053.31-084

\section{ДО ПИТАННЯ ПРОФІЛАКТИКИ ГНІЙНО-ЗАПАЛЬНИХ ЗАХВОРЮВАНЬ КОН'ЮНКТИВИ НОВОНАРОДЖЕНИХ}

\author{
С. О. Риков, К. Ю. Гріжимальська В. П. Ковальчук \\ Вінницький національний медичний університет ім. М. І. Пирогова \\ Національна медична академія післядипломної освіти ім. П. Л. Шупика
}

\begin{abstract}
В статье приведены результаты микробиологического исследования конбюнктивы 60 новорожденных в период нахождения их в роддоме и 116 детей с явлениями воспаления конбюнктивы. Всем детям определялся качественный состав микрофлоры конбюнктивы. Высокая степень инфицирования конбюнктивы детей УПМ в период нахождения их в роддоме свидетельствует о необходимости совершенствования средств и способов первичной ежедневной обработки глаз новорожденных.
\end{abstract}

Ключевые слова: профилактика конъюнктивитов новорожденных, микрофлора конъюнктивы, гнойно-воспалительные заболевания глаз у новорожденных, методы исследования микрофлоры конъюнктивы.

Ключові слова: профілактика гнійно-запальних захворювань кон'юнктиви, мікрофлора кон'юнктиви, гнійно-запальні захворювання очей у новонароджених, методи дослідження мікрофлори кон'юнктиви.

Вступ. Комплекс заходів догляду за очами новонароджених, що здійснюється у пологових будинках, націлений на профілактику гнійнозапальних уражень апарату зору, які складають серйозну проблему сучасної неонатології. У сьогоденні відомо, що викликати гнійні кон'юнктивіти у ново- народжених здатні чисельні види мікроорганізмів. Однак хронологічно першими введеними у медичну практику були заходи запобігання захворювань, обумовлених гонококами.

(C) С. О. Риков, К. Ю. Гріжимальська В. П. Ковальчук, 2012 
Гонорея - одне 3 найбільш поширених інфекційно-венеричних захворювань. За оцінками ВOO3, у світі щорічно реєструють понад 200 млн. хворих на гонорею. Частота виявлення гонореї у вагітних сягає 9,4 \%. Інфікування очей у новонароджених відбувається внутрішньоутробно чи під час проходження через пологові шляхи, пізніше - через предмети індивідуального догляду, забруднені виділеннями хворих на гонорею. Незважаючи на проведення запобіжних заходів, захворювання на гонобленорею в пологових будинках виявляють i зараз у 0,03-0,4 \% новонароджених.

Вперше в медичній практиці профілактику гонобленореї запропонував проф. акушерства та гінекології Львівського медичного університету д.мед.н. А. П. Матвєєв в 1862 році. Для профілактики були застосовані інстиляції $2 \%$ розчину нітрату срібла, одразу після народження [5].

Нітрат срібла у невеликих концентраціях має в’яжучу і протизапальну дію, у більш концентрованих розчинах коагулює тканини та бактерицидно діє не лише на збудника гонореї, але й на інших гноєтворних бактерій.

Наказом № 163 МО3 України від 12.06.1996р. було регламентовано застосування $30 \%$ розчину сульфацилу натрію з метою профілактики гнійнозапальних захворювань кон'юнктиви новонароджених. У пологових будинках усім без винятку новонародженим 3 профілактичною метою двічі закапували очі цим препаратом (негайно після народження дитини до відділення його від матері та через 2 години після народження - у дитячій палаті). Однак з'явились чисельні повідомлення про виникнення явищ подразнення кон'юнктиви у новонароджених та неефективність методу завдяки резистентності бактерій до препарату [3].

Наказом № 59 МО3 України від 10.02.2003 введено профілактику кон'юнктивітів $1 \%$ еритроміциновою або $1 \%$ тетрацикліновою мазями для очей (закладання мазі за повіки дитини).

Наказ № 152 МО3 України від 04.04.2005 рекомендує застосування $1 \%$ тетрациклінової мазі як профілактичного засобу.

Спектр протимікробної дії препарату охоплює широкий перелік грамнегативних бактерії, у т. ч. збудників особливо небезпечних інфекцій (холери, чуми, туляреміі, бруцельозу). Позитивною характеристикою препарату $є$ висока протимікробна активність у відношенні внутрішньоклітинних паразитів, у т.ч. хламідій. На жаль переважаюча більшість клінічно значущих штамів стафілококів, стрептококів, протеїв і паличок синьо-зеленого гною, здатних викликати запалення слизової оболонки ока, є нечутливими до препаратів тетрациклінового ряду.

Еритроміцинова очна мазь виявляє ефективність у боротьбі з хламідійною і коковою інфекці$€ ю$ однак не впливає на грамнегативні бактерії.
Як спосіб профілактики офтальмії новонароджених в науковій літературі описано застосування розчину йод-повідону. В 2003 році ряд зарубіжних авторів провели широке дослідження на 719 новонароджених, в результаті якого була доведена ефективність інстиляцій йод-повідону у профілактиці гонобленореї $[6,7]$.

Повідон-йод є комплексною сполукою іонізованого йоду і полівінілпіролідону. У такому складі йод не чинить грубого коагулюючого впливу на протеїни подібного дії молекулярного йоду. Однак цілком виключити його шкідливий вплив на чутливий епітелій рогівки навряд чи можливо.

Існує досвід використання 3 профілактичною метою очних крапель на основі антибіотиків аміноглікозидного ряду, четвертинних амонієвих сполук та інших антисептичних засобів. Проте, у кожному випадку виявляються свої «за» і «проти» при використанні тих чи інших лікарських препаратів. Тим більше, що спектр етіологічно значимої мікрофлори є надзвичайно динамічним і виявляє вражаючі адаптивні властивості. Вибір оптимального засобу для профілактики гнійно-запальних уражень кон'юнктиви новонароджених потребує дослідження сучасного стану етіологічної структури гнійно-запальної патології очей новонароджених та вивчення чутливості збудників до наявного арсеналу протимікробних очних лікарських засобів.

Метою нашої роботи було вивчення мікрофлори кон'юнктиви новонароджених та спектру збудників кон'юнктивітів періоду новонародженості, порівняльне дослідження їх чутливості до сучасних антимікробних очних препаратів.

МАТЕРІАЛ ТА МЕТОДИ. Вивчення мікрофлори, що колонізує кон'юнктиву новонароджених, проведено у 60 дітей, народжених природним шляхом без ускладнень і виписаних здоровими додому на четвертий день після пологів. Бактеріологічне обстеження кон'юнктиви проведено одразу після народження, на другій добі перебування у пологовому будинку та перед випискою із стаціонару. Етіологічну структуру гнійних кон'юнктивітів вивчено у 116 дітей, у яких ознаки запалення слизової оболонки ока виникли до 28 доби життя.

Матеріал для дослідження забирали стерильним стандартним ватним тампоном окремо з кон'юнктиви правого та лівого ока. Виділення факультативно-анаеробних бактерій проводили шляхом прямого висіву на кров'яний м'ясопептонний агар без підрощування у рідкому поживному середовищі [4]. Ідентифікацію виділених культур здійснювали за сукупністю морфологічних, культуральних та біохімічних ознак. Чутливість виділених штамів до антимікробних препаратів досліджували методом серійних послідовних двократних розведень у рідкому поживному середовищі у відповідності п. 3.2. методичних вказівок, затверджених наказом № 167 МОЗ України від 05.04.2007 р. [1, 2]. Мінімальну бактерицидну концентрацію (МБцК) визначали шляхом висіву з кожного розведення препарату після добової інкубації при $37^{\circ} \mathrm{C}$ на щільне поживне середовище. Вираховували середні показники МБцК для всіх виділених штамів одного біологічного виду мікроорганізмів. Співставлення середніх 
концентрацій різних препаратів, необхідних для знищення мікроорганізмів, дозволяє визначити порівняльну активність у відношенні тих чи інших мікроорганізмів. Визначення чутливості гонококів до протимікробних засобів проводили на штамах, виділених від дорослих, хворих гонореєю. Отримані результати оброблені статистично [4].

Усі діти були оглянуті неонатологом та офтальмологом. Для огляду кон'юнктиви, переднього відділу та додаткового апарату ока використовували запропонований нами прилад (патент України № 58935 від 26.04.2011р. «Пристрій для обстеження додаткового апарата ока, кон'юнктиви та переднього відділу ока у новонароджених»). Пристрій використовується таким чином. Одягають на голову бінокулярну стереоскопічну лупу з освітлювачем, регулюють дистанцію між центрами зіниць, вмикають освітлювач, що знаходиться безпосередньо в приладі. Світло з освітлювача наводять на повіку лівого ока. Руки залишаються вільними і ними при необхідності повертають і фіксують головку новонародженого. Оцінюють стан шкіри повік, її колір, наявність крововиливів, набряку, висипань. Оглядають край повіки . Правою рукою надавлюють на ділянку сльозного мішка, лівою рукою вивертають нижню повіку і оглядають стан нижньої сльозної точки на наявність чи відсутність виділень 3 неї. Потім великими пальцями обох рук розводять повіки і детально оглядають кон'юнктиву (наявність крововиливів,фолікулів, висипів, інфільтратів, набряку, оцінюють її колір), маніпулюючи правою і лівою рукою, вивертають нижню і верхню повіки, оцінюють стан кон'юнктиви, положення сльозних точок, характер виділень, стан переднього відділу ока, а саме діаметр рогівки, її прозорість, глибину та вміст передньої камери, стан райдужки та реакцію зіниці на світло.

Для оцінки числових показників розраховували середнє арифметичне значення (M) i помилку середнього (m). В залежності від характеру отриманих даних застосовувались відповідні методи статистичного аналізу.

РЕЗУЛЬТАТИ ТА ЇХ ОБГОВОРЕННЯ. Результати бактеріологічного дослідження матеріалу, отриманого безпосередньо після народження, показали, що в 52,2 \% випадків кон'юнктива не є стерильною. У 33,3 \% обстежених з числа тих, у яких зразу після народження мікроорганізми не висівалися, при повторному бактеріологічному дослідженні кон'юнктива була колонізована факультативно-анаеробними бактеріями. На момент виписки із стаціонару у 89,4 \% дітей слизові оболонки ока були заселені мікроорганізмами.

Як свідчать наведені на малюнку 1 дані, найбільш частими контамінантами кон'юнктиви новонароджених є представники нормальної мікрофлори шкіри і слизових оболонок - епідермальні стафілококи (52\%). Золотисті стафілококи, які є бактеріями з високим патогенним потенціалом, виявлені у 4 \% обстежених. Високим був показник виділення фекальних ентерококів (32 \%). Заселеною грамнегативною флорою виявилась кон'юнктива у $12 \%$ новонароджених. 3 їх числа у 8 \% випадків виявлені синьогнійні палички.

Усі означені вище види мікроорганізмів належать до умовно-патогенної нормальної мікрофлори тіла дорослих людей $[1,2]$. Так, носіями золотистих стафілококів на слизовій оболонці носоглотки є близько $25 \%$ здорових дорослих. У $20 \%$ здорових людей золотистими стафілококами колонізована шкіра промежини. Епідермальні стафілококи зустрічаються на шкірі і слизових усіх людей. Ентерококи, ешерихії і палички синьо-зеленого гною в нормі вегетують на слизовій кишечника. Однак відомо, що у випадках зміни епітопу існування у організмі людини чи при наявності дефектів імунітету ці види можуть провокувати розвиток запальних процесів [4].

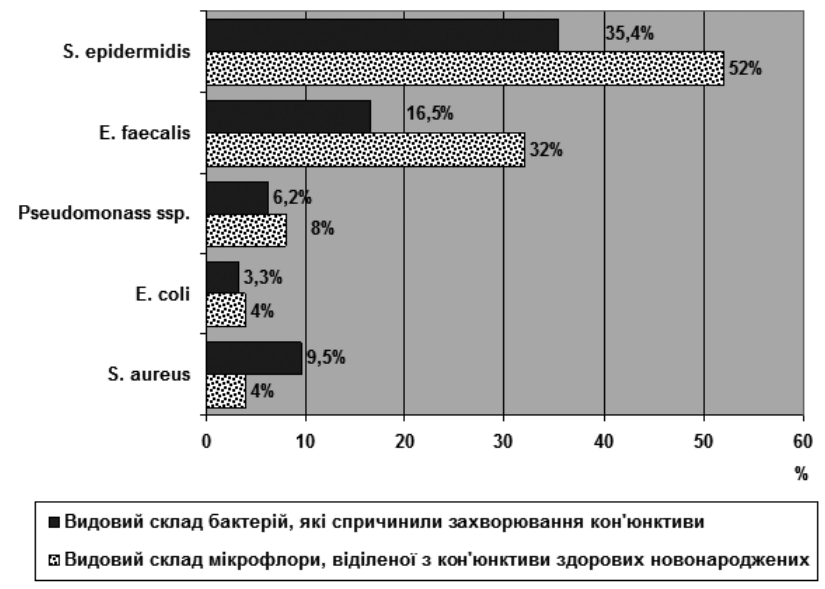

Мал. 1. Видовий склад мікрофлори, виділеної з кон'юнктиви здорових новонароджених та склад бактерій, які спричинили захворювання.

Значний інтерес являє співставлення наведених вище даних про частоту виділення мікроорганізмів з кон'юнктиви здорових новонароджених і етіологічної структури кон'юнктивітів дітей періоду новонародженості. Роль окремих видів бактерій у розвитку кон'юнктивітів ілюструє малюнок 1.

Епідермальні стафілококи, що найчастіше контамінували здорову кон'юнктиву, правомірно зайняли перше за частотою місце серед мікроорганізмів, виділених з уражених запаленням очей $(35,4 \%)$. Слід зазначити, що у вигляді монокультур епідермальні стафілококи були виділені у 28,4 \% випадків. У решти обстежених цей вид бактерій приймав участь у розвитку запалення в асоціаціях з золотистими стафілококами, ентерококами. Золотисті стафілококи виділені з вмісту кон'юнктивального мішка 9,5 \% пацієнтів з кон'юнктивітом. Загалом стафілококова флора у вигляді монокультур і в асоціаціях з іншими мікроорганізмами виявлена у 45,7 \% хворих.

Роль ентерококів у розвитку кон'юнктивітів новонароджених доведена у 16,5 \% випадків, що також у певній мірі корелює з частотою виділення цього виду бактерій із здорової кон'юнктиви. Грамнегативні бактерії спричинили запалення у 9,5\% обстежених. 3 їх числа у 6,2 \% обстежених виділені палички синьо-зеленого гною, а у 3,3 \% - кишкові палички.

Співставлення графічних зображень на малюнку 1 наочно демонструє схожість наведених на них 
даних і дозволяє зробити висновок про те, що бактеріальна мікрофлора, яка колонізує кон'юнктиву новонароджених у перші дні життя, в подальшому відіграє провідну роль у розвитку гнійно-запальних уражень ока. Адже у жодному дослідженому випадку нами не виділено збудників гонобленореї, на яких націлені профілактичні заходи у пологових стаціонарах. Між тим умовно-патогенні представники нормофлори шкіри і слизових травної системи виділені у переважної кількості дітей з ознаками запалення кон'юнктиви. Вочевидь даний епітоп заселення та недосконалість механізмів імунного захисту у період новонародженості є достатніми умовами для реалізації патогенного потенціалу нешкідливих у інших випадках бактерій. Викладене вище обгрунтовує важливість правильного вибору засобів санації кон'юнктивального мішка [1].

3 цією метою нами визначено рівень чутливості виділеної мікрофлори до восьми протимікробних лікарських препаратів, що широко використовуються в сучасних умовах в практичній офтальмології. Результати досліджень наведені у таблиці 1.

Таблиця 1

Результати визначення чутливості мікроорганізмів до очних протимікробних препаратів

\begin{tabular}{|l|c|c|c|c|c|c|c|c|}
\hline \multirow{2}{*}{ Вид бактерій } & \multicolumn{7}{|c|}{ Мінімальна бактерицида концентрація препарату (МБцК мкг/мл) М $\pm \mathbf{m}$} \\
\cline { 2 - 9 } & тетрациклін & ерітроміцин & тобраміцин & $\begin{array}{c}\text { ципроф- } \\
\text { локсацин }\end{array}$ & $\begin{array}{c}\text { лівофлокса- } \\
\text { цин }\end{array}$ & офлоксацин & $\begin{array}{c}\text { декаметок- } \\
\text { син }\end{array}$ & мірамістин \\
\hline S.aureus & $38,5 \pm 11,3$ & $85,4 \pm 17,4$ & $2,9 \pm 0,4$ & $237,2 \pm 24,9$ & $78,6 \pm 14,1$ & $17,6 \pm 3,9$ & $3,4 \pm 0,9$ & $17,1 \pm 4,1$ \\
\hline S.epidermidis & $192,7 \pm 41,9$ & $120,9 \pm 22,3$ & $137,4 \pm 18,5$ & $184,7 \pm 22,3$ & $92,3 \pm 14,8$ & $47,7 \pm 11,3$ & $1,6 \pm 0,4$ & $20,6 \pm 6,5$ \\
\hline E. faecalis & $312,2 \pm 65,1$ & $37,4 \pm 10,5$ & $23,4 \pm 6,2$ & $73,6 \pm 16,8$ & $36,9 \pm 9,2$ & $32,6 \pm 2,7$ & $1,7 \pm 0,6$ & $4,6 \pm 1,7$ \\
\hline E.coli & $17,6 \pm 4,3$ & $1237,2 \pm 135,4$ & $15,1 \pm 4,6$ & $8,3 \pm 1,6$ & $4,2 \pm 0,6$ & $9,6 \pm 1,9$ & $9,8 \pm 2,1$ & $14,7 \pm 2,5$ \\
\hline P.aeruginosae & $17,6 \pm 4,3$ & $1491,5 \pm 160,7$ & $7,9 \pm 1,4$ & $19,2 \pm 3,7$ & $18,7 \pm 3,9$ & $54,9 \pm 12,3$ & $78,6 \pm 26,7$ & $85,4 \pm 27,9$ \\
\hline N.gonorrheae & $14,5 \pm 3,7$ & $18,7 \pm 5,2$ & $12,7 \pm 2,8$ & $4,1 \pm 0,7$ & $3,3 \pm 0,6$ & $4,3 \pm 0,8$ & $1,1 \pm 0,2$ & $2,4 \pm 0,4$ \\
\hline
\end{tabular}

Аналіз даних таблиці 1 свідчить про істотні відмінності у чутливості збудників кон'юнктивітів новонароджених до різних офтальмологічних препаратів. Тетрациклін характеризується низьким рівнем активності до переважної більшості виділених бактерій. Нечутливими до нього виявились палички синьо-зеленого гною. Понад 30 \% виділених штамів епідермальних стафілококів виявились стійкими до препарату і не гинули у присутності 1000 мкг/мл тетрацикліну. Решта штамів цього виду, мінімальна бактерицидна концентрація (МБцК) препарату для яких становила $(192,7 \pm 41,9)$ мкг/мл, слід характеризувати як помірно чутливі. 3 метою порівняння, слід зазначити, що необхідна для знищення цього виду мікроорганізмів концентрація декаметоксину у 120 разів менша $(1,6 \pm 0,4)$ мкг/мл.

Серед ентерококів тільки 7 \% виділених штамів виявили чутливість до тетрацикліну в концентрації $(312,2 \pm 65,1)$ мкг/мл. Решта були резистентними до препарату. Задовільний рівень чутливості до тетрацикліну виявляли лише кишкові палички та збудники гонобленореї.

Низький рівень чутливості сучасний перелік збудників кон'юнктивітів новонароджених виявляв до антибіотика макролідної структури еритроміцину. Лише для знищення ентерококів і збудників бленореї достатньо було концентрації препарату меншої, ніж 50 мкг/мл. Однак цей показник у 22 рази вищий, ніж аналогічний для декаметоксину.

Значно кращі характеристики протимікробної активності у відношенні досліджених штамів бактерій належать очним краплям, основною діючою речовиною яких є антибіотик аміноглікозидного ряду тобраміцин. Особливо слід відзначити високу активність препарату у відношенні синьо-гнійних паличок. Однак епідермальні стафілококи, що найбільш часто спричиняють запалення кон'юнктиви, виявились помірно чутливими до препарату -

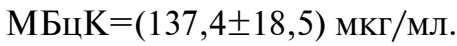

Очні лікарські форми на основі фторхінолонових сполук виявляли високий рівень активності у відношенні грамнегативних збудників запальних процесів. Навіть найвитриваліші до протимікробних засобів палички синьо-зеленого гною до ципрофлоксацину і лівофлоксацину виявляли високий рівень чутливості. Проте, стафілококи і ентерококи, загальна питома вага яких у етіологічній структурі кон'юнктивітів новонароджених сягає $60 \%$, були помірно чутливими до цих препаратів

Мірамістин та декаметоксин належать до антисептиків з ряду поверхнево-активних четвертинних амонієвих сполук і характеризуються найвищим рівнем активності у відношенні переважної більшості виділених бактерій. Мірамістин істотно переважає тобраміцин і фторхінолони по активності у відношенні усього спектру кокової мікрофлори і незначно поступається їм по дії на кишкові палички. До препарату виявляють задовільний рівень чутливості палички синьо-зеленого гною. Однак штамові відмінності у чутливості дозволяють передбачити відсутність лікувальної і профілактичної ефективності препарату в окремих випадках, обумовлених цим видом бактерій. Адже МБцК препарату для псевдомонад, за нашими даними, коливається у межах $(85,4 \pm 27,9)$ мкг/мл, а концентрація діючої речовини у лікарській формі становить 100 мкг/мл. 
Найвищий рівень чутливості виділена кокова мікрофлора виявила до декаметоксину. За показником МБцК декаметоксин істотно активніше впливає на стафілококи і ентерококи, ніж мірамістин та фторхінолони. Високий рівень чутливості до препарату виявляли кишкові палички (МБцК=9,8 2 , 1 мкг/ мл). Найвищий з усіх досліджених препаратів рівень активності декаметоксин виявив у відношенні збудників гонобленореї. Палички синьо-зеленого гною виявились помірно чутливими до декаметоксину (МБцК=78,6 $\pm 26,7$ мкг/мл). Однак концентрація основної діючої речовини у препараті (200 мкг/мл) істотно перевищує необхідну МБцК, навіть з урахуванням коливань у чутливості окремих штамів.

Узагальнюючи наведене вище, слід зазначити, що умовно-патогенна мікрофлора, яка колонізує слизову кон'юнктиви новонароджених у перші години і дні життя, здатна в подальшому спричиняти запальні процеси ока. Специфічні патогени, подібні нейсеріям гонореї, в сучасних умовах рідко спричиняють запальні процеси кон'юнктиви новонароджених. Однак, як і у попередні часи, санація кон'юнктивального мішка під час перебування дитини у пологовому будинку має важливе профілактичне значення. 3 числа наявного арсеналу протимікробних очних лікарських форм найбільш ефективними засобами профілактики слід вважати очні краплі на основі четвертинних амонієвих сполук - декаметоксину і мірамістину. Саме до цих препаратів найвищий рівень чутливості виявляють не лише специфічні збудники бленореї, але й умовно-патогенні контамінанти кон'юнктиви, що найчастіше приймають участь у збудженні запальних процесів.

\section{ВИСНОВКИ}

1. В сучасних умовах кон'юнктивіти у дітей періоду новонародженості у переважаючій кількості випадків викликаються не специфічними облігатними патогенами, а умовно-патогенними представниками нормальної мікрофлори тіла людини, що контамінують слизову оболонку ока у перші го- дини і дні після народження. Висока частота неспецифічних запальних процесів у новонароджених може бути пояснена незавершеністю формування механізмів імунного захисту.

2. 3 числа наявних протимікробних офтальмологічних лікарських препаратів, з урахуванням рівня чутливості мікрофлори кон'юнктиви до їх дії, для профілактики гнійно-запальних уражень слизової оболонки ока новонароджених доцільно використовувати очні краплі на основі антисептиків 3 числа четвертинних амонієвих сполук.

\section{ЛІТЕРАТУРА}

1. Боброва Н. Ф., Дембовецька А. Н. Консервативное лечение флегмоны слезного мешка // Мат. научнопракт. конф. дитячих офтальмологів України «Вроджена та генетично обумовлена сліпота та слабкозорість. Проблеми діагностики, обстеження та комплексне лікування». Партеніт, Крим 2009. - С.38-39.

2. Боброва Н. Ф., Молодая А. Л. Микрофлора при конъюнктивитах и дакриоциститах новорожденных и ее чувствительность к антибактериальным препаратам. // Офтальмол. журн. - 2011. - № 6. - С.4-7.

3. Кураєнко В. П., Кузьменко К. Е. Чи є проблема гонобленореї актуальною в Україні.//Укр. журн. дерматології, венерології, косметології. - 2005. № 3. - C.74-76.

4. Широбокова В. П. //Медична мікробіологія, вірусологія та імунологія: підручник для студ. вищ. мед. навч. закладів // Видання 2-е. - Вінниця: Нова Книга, 2011. - 952 с.

5. Степанковская Г. К., Сахарова И. А. Хроника научной и лечебно-профилактической деятельности кафедры акушерства и гинекологии № 1 медицинского университета им. А. А. Богомольца за 165 лет ее существования // Междунар. мед. журнал. - 2006. - № 1. - С. 78-83.

6. Isenberg S. J., Apt L. A controlled trial of povidone-iodine as prophylaxis against ophthalmia neonatorum // N. Engl.J.Med. - 2003. - № 3. - P. 562-566.

7. Schaller V. C., Klauss V. Is Crede's prophylaxis for ophthalmia neonatorum still vallid? // Bull WHO. - 2001. 79. - P.262-3.

Поступила 25.10.2011

Рецензенты: д. м. н. Н. Ф. Боброва, зав. лаб. микробиологии А. Л. Молодая

\section{TO THE QUESTION OF PREVENTION OF PYOINFLAMMATORY DISEASES OF CONJUNCTIVITIS OF NEWBORNS}

\section{S. Rykov, K. Grygimalskaya, V. Kovalchuk}

Kiev, Ukraine

In the article the results of microbiological research of conjunctivitis of 60 newborns in the period of their being in the maternity hospital and 116 children with the flammatory of conjunctiva are given. All children were indentified both quality structure of microflora of conjunctiva. The high degree of infection of conjunctiva of children at the period of their being in the maternity hospital testifies necessity of improvement of tools and methods of every day treatment eyes of newborns. 